\title{
FUNDAMENTAL VALUES IN NEW DEMOCRACIES: THE PRINCIPLE OF REPRESENTATION IN THE SERBIAN CONSTITUTION ${ }^{* * *}$
}

\begin{abstract}
In this paper, the author analyzes the process of establishing a system of fundamental values in the rule of law in the context of constitutional discontinuity by exploring the concept of representative mandate as a basic constitutional principle in new democracies. The first part contains general considerations on the relationship between the constituent power and the fundamental values, as well as the (non)legal factors which should provide both for the establishment of constitutional rules and their interpretation for the purpose of upholding the fundamental values. The subject matter of analysis in the second part are citizens' value judgments on the representative mandate, which point out to the evolutive pattern underlying this principle both in the developed and in the developing democracies. Taking into account a discrepancy between the existing and the proclaimed constitutional system in Serbia, the third part of the paper contains a proposal for instituting a set of prospective constitutional measures to support citizens' value judgments on the representative mandate.
\end{abstract}

Key words: Constitutional Democracy, Principle of Representation, Serbian Constitution.

\footnotetext{
“irena@prafak.ni.ac.rs

*This paper is accepted and published on the official site of the IX World Congress of Constitutional Law: "Constitutional Challenges: Global and Local”. Norway, Oslo. June. 2014. https://www.jus.uio.no/english/research/news-and-events/ events/conferences/2014/wccl-cmdc/wccl/papers/ws10/w10-pejic.pdf

${ }^{* *}$ Рад је резултат истраживања на пројекту „Заштита људских и мањинских права у европском правном простору“, бр. 179046, који финансира Министарство за науку и технолошки развој РС у пројектном циклусу 2011-2014.
} 


\section{Introduction}

The adoption of any new constitution is based on the assumption that it rests on the principle of legitimacy, which is two-fold: first, the legitimacy of the formal process of adopting the constitution and, second, the legitimacy of establishing a general normative framework for a prospective development of a system of fundamental values. The constitution establishes "a morally superior set of values, rights and principles", which are the guiding principles of social and political life (Pasquino, 1998, p. 45). Hence, the constitutional and the value system may not be observed in isolation because they are largely interrelated and complementary. Nor may the circumstances in which the constituent power creates a framework of a fundamental value system be observed without taking into account a range of diverse (non)legal factors which contribute to shaping the constitutional principles and their interpretative evolution.

Being the cornerstone of constitutional democracy, the constitutional principle of representation is one of the fundamental values which deserve special consideration. Given the fact that this principle and the entire system based on the separation of powers are necessarily subject to change even in traditional (developed) democracies, the confusion and disorientation encountered by new democracies (such as Serbia) in the process of shaping citizens' value judgments is by far more substantial. The Serbian scholars have beencaught in the trap of trying to "defend" the liberal principle of free parliamentary mandate, which made citizens suspicious and distrustful towards the entire value system proclaimed under the Serbian constitution.

\section{The Constituent Power and the System of Fundamental Values}

Being interpreted by the constitutional judicature and perceived in the constitutional theory as a presumption of the legal order, constitution articulates some fundamental values which reflect the attitude of the constitution founding framerstowards the system of fundamental values. Although the constituent power should be ideologically neutral in performing its constitutional function, it may not be value-neutral. In the opinion of K. Hesse (Hesse, 1982: 4), the conception of "values" (Wertordnung) gives rise to ample questions, such as: what the constitution norms as a value, why and to what extent the constitution builds the "system", how the constitutional change can be justified and how extensive the change may be, particularly in terms of the established "value system"?

Traditional democracies constantly pose these questions and reassess the answers to these questions. However, the multifaceted problem is additionally complicated in the circumstances when one system of values is substituted by another. Questions keep piling up in the event of constitutional discontinuity, 
when there is no possibility to provide for a "peaceful" transformation of value standards which are commonly associated with continuing interpretation of constitutional principles. The written constitution is not subject to constitutional change only through constitutional revision; the change also implies an evolution in understanding and interpretation of the basic constitutional principles. ${ }^{1}$ The interpretative evolution involves the need to upgrade the basic constitutional principles, thus providing for a more rational communication of fundamental values embodied in the constitutional and political culture.

In new democracies, the constitutional theory and jurisprudence have encountered a new dilemma: which value standards should the constituent power be governed by when drafting a new constitution, and what are the boundaries of interpretation of constitutional principles in case of constitutional discontinuity? ${ }^{2}$

The Serbian constitutional theory is still probing for answers to these questions, which are also pertinent to many other Eastern European countries. At the end of the $20^{\text {th }}$ century, the constitutional transformation of Serbia ensued on multiple scales after breaking away from the socialist system of government, which featured a specific horizontal and vertical organizational structure of the state. Despite the attempts of the constitution framers to ensure the constitutional continuity by adopting the new democratic constitutions (1990. and 1992.), it was evident that the value system had to be rebuilt from scratch. Nowadays, after several constitutional and political changes, the Serbian governing authorities seem to have lost their bearings in the search of the basic value standards. ${ }^{3}$

On the basis of the historical and comparative experience, a possible solution may be to reconsider the two obvious alternatives. The first option implies that the constitutional system shall return to the roots of liberal constitutionality; this model had been the predominant model of constitutional design in Serbia from the early $19^{\text {th }}$ century. Another option would be to skip the phase of constitutional

1 G. Burdeau points out that the evolution of a written constitution may be significant in terms of generating the conditions in which the constitution is applied and interpreted. (Burdeau, Hamon, Troper, 1995: 51)

2 The term "discontinuity" is used here to denote not only the disruption with the previous legal order but also with the established value system. In that context, we consider that the countries which traditionally develop the model of democratic constitutionality endeavor to ensure the continuity of both the legal and the value system.

3 Ten years after the adoption of the democratic constitutions, Lidija B.Fleiner explained it as follows: "The first ten years of transformation have convincingly demonstrated that - due to the historical context within which the democratic transition is taking place in Central and Eastern Europe - a liberal constitutional and democratic design for itself does not necessarily create a democratic polity properly taken, which functions under the rule of law." (Fleiner, 2001: 33) 
liberalism and directly employ the rules of the developed constitutional welfare state. Resting on the separation of powers and guaranteed human rights, the latter option implies that the constitutional model shall guarantee new values, such as: multiculturalism, democratic potential of minorities in the political system, strengthening the constitutional unity through diversity of political options, and promoting civic awareness considering that there is a lack of perception (and frequently express disapproval) that the national identity may be regarded as the constitutional identity.

The experiences of countries with much longer democratic tradition confirm that the dilemma encountered by developing democracies is nothing new. Thus, towards the end of the $20^{\text {th }}$ century, the British constitutional authorities had a dilemma about the values underlying a potential revision of the British constitution, particularly concerning the "suitability of the constitution to the political realities of post-industrialist, multi-racial, multi-party and relatively egalitarian society", which Britain had developed into ${ }^{4}$. In the opinion of Bruce Ackerman, neither the French nor the British had ever had much faith in the power of the written constitution to "constrain the democratic politics". In similar terms, Ackerman asserts that the contemporary American theory and practice have moved in the direction of "emphatic provincialism" (Ackerman, 1997: 772).

There is no dispute about the key hypothesis that the genesis of a constitutional order is not bound by formerly-enacted rules, and that the constituent power (pouvoir constituante) as the constituting power is not legally bound either. However, this hypothesis may be considered in relation to other non-legal factors, such as the constitutional culture and a developed value system; although they do not have a direct impact on generating a formal legal pattern and selection of a constitutional model, these factors still significantly shape the modalities of their application, particularly in transforming the constitutional principles into laws. ${ }^{5}$

This aspect of understanding the constituent power rests on the dual conception of the constitution, which is perceived in the formal sense and in the material sense. It was long ago that the constitutional theory determined that the concept of "constitution" does not imply only a specific form "enveloping" the materia constitutionis.The French theorist L. Duguit pointed out that a formal constitution may be misleading because "the facts are stronger than the constitution".

4 There are opinions that "the new stress on participant attitudes and behavior collides with values anciently embedded in the political system". (Turpin, 2002: 5)

5 The actual impact of "the constitutional culture" may be reflected in the emergence of a fundamental principle or a basic rule which is generated through constant recurrence and on the basis of a general consensus; consequently, the constituent power may change such a rule (custom or convention) only through constitutional revision. (Maunz, Zippelius, 1994: 37) 
Similarly, American jurists emphasized that the "law in books" is not necessarily the same as the "law in action". In addition to the formal (written) sources, a constitution in material sense presumes the existence of some informal (unwritten) sources, which ensure permanence and stability to the constitution and which are developed in a specific "value-driven environment". The German constitutionalists T.Maunz and R.Zippelius pointed out that an on-going process of creating the constitution over a period of time results in creating a "mature" or "fully-grown" constitution. ${ }^{6}$ We consider that this phase may be understood in the broadest sense as a creation of a "mature" constitutional and value system. The constitutional culture plays a significant role in that context because the feelings and opinions of the general public support the constitutional principles to a much greater extent than legal norms including specific content and sanctions, frequently used as a threat (Turpin, 2002: 5). In the contemporary constitutional theory, many authors point out that constitutional culture is one of the essential elements of constitutionalism (along with justice and power). ${ }^{7}$ Thus, constitutional culture is identified with Ch. Montesquieu's conception of "the spirit of the laws" and A.Tocqueville's conception of "habits of the heart".

In the process of establishing a new value system, the constituent power cannot accomplish its legitimacy at once. The citizens' trust may be earned only through a persistent effort of the constituting power to develop a system of fundamental values. In other words, legitimacy rests on the confidence which the constituting power enjoys at the moment when citizens' value judgments have not been developed yet; therefore, it may be more accurate to designate a value system as a legitimate goal which the constituent power pursues in the course of creating the constitution as the supreme general legal act. For this reason, the debate on the adoption of the first/new constitution has to extend to assessing the impact of non-legal factors on the constituent power, which is not bound by any previous laws. In that context, it may be essential to address the following question: what is the correlation between the formal constitution and the value system; in particular, can a value judgment be taken from another legal system and established under the same pattern just as the formal mechanisms governing the operation of the rule of law?

6 The terms "mature" or "fully-grown" constitution ("gewachsenen"Verfassung) points out to its permanent value and prospects (Maunz, Zippelius, 1994: 30). On the other hand, the British constitutional literature contains an expression "historical constitution", which also points out to its permanent value which remained "stuck" in the past (Turpin, 2002: 5) due to specific circumstances. What these two concepts of constitution have in common is the content which includes not only formal (written) rules enacted by competent authorities but also the unwritten rules articulated through constitutional customs and conventions.

7 There are opinions that a good constitution should be a "coherent whole" including three key elements: culture, power and justice, which are traditionally "at war" but tend to be "in accord". (Lutz, 2006: 18) 
In an attempt to provide arguments for a potential response, we must take into account that similarities generally outnumber the differences among the new constitutions created in Europe and worldwide in the last decades of the $20^{\text {th }}$, which was not the case in the early developmental phases of constitutional history. Whereas the first written constitutions were original works developed on the grounds of specific origin or particular circumstances in which the constitutional states had developed, contemporary constitutions include almost identical constitutional solutions on the separation of powers, human rights and economic (neo)liberalism. However, the world-wide expansion of democratic constitutionality does not necessarily entail an equivalent and sufficient development of the fundamental value system which is to uphold the rule of law. This trend of "looking up to others" or replicating the constitutional models of other states has become almost universal in the contemporary constitutional context.Constitutional history bears evidence that this trend was also common at the time when the newly-established states (former colonies) adopted their first post-colonial constitutions, often replicating the constitutional documents of the former metropolises ${ }^{8}$. The consequences of replicating the constitutional solutions of another state are two-fold: on the one hand, the lack of originality and a maladjustment to political and social environment yield negative effect contrary to those that a constitution is supposed to produce; on the positive side, the attainments of the democratic constitutionality have (thus) been extended to newly-established systems which tend to develop the value system by engaging in an on-going interpretation of constitutional rules.

\section{Value Judgments about the Representative Mandate}

In order to evaluate the achievements of a value system, we may examine the basic postulates of the rule of law: the principle of the separation of powers and the guaranteed human rights. These two complementary fields of materiae constitutionis may demonstrate the scope of misconceptions that the constitutional and political actors may develop about the "values" of constitutional democracy, which may eventually impede the "defense" of citizens' value judgments. The rule of law may be designated as the cornerstone of contemporary constitutional democracy. One of the basic functions of the constitution is to declare the fundamental constitutional principles, which justify the provisions contained in other constitutional norms and allow for the interpretation of the constitution (Burdeau, Hamon, Troper, 1995, p. 52). The countries of underdeveloped democratic tradition failed to accomplish this principal goal in the earliest stage of constitutional development (i.e. at the time of introducing the principle of popular sovereignty in the parliamentary representation system).

8 The process of "globalization of constitutionalism" (Go, 2003: 72) is most prominent in the development of the post-colonial constitutions in the second half the $20^{\text {th }}$ century. 
Being one of the pillars in the doctrine of parliamentary democracy, the constitutional principle of free parliamentary mandate was put to a serious test in newly developed constitutional systems. Originally conceived within the framework of the liberal constitutionality, this principle was subject to significant transformation in the circumstances of the $20^{\text {th }}$ century multi-party system. As the number of participants in the representative system increased and the rules of the political game changed, it could have been assumed that the free parliamentary mandate would experience a transformation in the constitutional state. However, the evolutive pattern took a different turn under the threat of another (socialist) ideology which developed in the mid-20 ${ }^{\text {th }}$ century, giving impetus to establishing the imperative mandate. Thus, the (liberal) principle, which was a value standard of representative democracy, was strengthened on the basis of ideological discrepancy with another type of (socialist) constitutionality, even though the evolution of this principle clearly indicated the need to adjust this liberal principle to the contemporary circumstances (first in Western democracies where it was originally created) so that it could serve as a model in newly established constitutional democracies (Köchler, 1995).

Towards the end of the $20^{\text {th }}$ century, the divide in the tissue of constitutional reality of the new democracies was so wide open that it was necessary to dispense with the former socialist model and accept a completely new system of values. The prominent feature of socialism was the imperative mandate, which rested on the party monism and state-imposed restrictions on human rights (particularly the freedom of thought, opinion and expression). In the new wave of democratic constitutionality, the Serbian authorities enthusiastically proclaimed the ideas of representative democracy resting on the original liberal principles. Thus, the Serbian constitutional theory and judicature tried to "defend" the ideal of free parliamentary mandate whereas the citizens were not (fully) aware of the importance of individual freedoms and postulates of the representative democracy. The model was supported in the European professional circles and embodied in the Opinion on the Constitution of the Republic of Serbia issued by the Venice Commission (European Commission for Democracy through Law, Opinion No. 405/2006). Yet, the authorities seem to have failed to acknowledge the fact that there are several schools of thought in democratic theory proposing different way of determining the content of representation. Thus, the neo-Rousseauean school of thought insists on the Jean-JacquesRousseau's postulates governing the mutual relations between the constituents and elected representatives, including the radical idea on a delegated mandate (where an MP is regarded as a delegate). A completely opposite standpoint is proposed by another theory which is based on EdmundBurke's concept of free parliamentary mandate. Although substantially conservative in its origin, the neo-Burkean theory starts 
from the assumption that the representatives are a kind of "guardians" whose mandates are vested in them by the voters. The third school of thought is the liberal theory of representative democracy which endeavors to reconcile "the capacity of the elite and mass participation" (Krouse, 1982: 524).

The authorities were caught in a trap because their insistence on the values of a liberal principle was in contradiction with the Serbian constitutional practice and political experience. The concept of "winning freedom" was misinterpreted by the elected representatives (MPs) who perceived it as an opportunity for trading off their mandates in the Serbian National Assembly; on the other hand, the citizens thought that the MPs' "freedom" should be restricted and the free mandate should be "returned" to the political parties which could freely dispose of the mandates. The free parliamentary mandate was generally perceived as a source of abuse (at voters' expense). The citizens did not perceived the mandate as an embodiment of their popular sovereignty in a democratic state but as an "alienated asset" belonging to political parties, which should be allowed to dispose of the mandate in compliance with the Constitution 2006. (Art. 102). ${ }^{9}$ Thus, instead of protecting the constitutional principle and building the value system upon it, Serbia has faced other problems because some other fundamental principles (such as the principle of popular sovereignty and the principle of political pluralism) have also lost their constitutional credibility. There was a reversal of hypotheses: while the constitutional theorist tried to "defend" the value judgment on the free mandate as a principle which is closely related to the popular sovereignty, politicians raised the issue of free mandate ownership (i.e. who owns the mandate: the MP or the political party). Meanwhile, being unaware that the representative mandate originally belongs to them, the citizens believed that the best solution would be to introduce the imperative mandate, which links the elected representative to the party rather than to the voters.

The Serbian constitutional theory seems to have ended up in a blind alley because a vast majority of authors stood in defence of the free parliamentary mandate ${ }^{10}$. It was a result of the need to weigh the options and establish a more rational solution for the stabilization of the constitutional and political democracy: should the state introduce clear legal sanctions governing the party discipline (which

9 The Constitution of Serbia (Art. 102.2) states:"Under the terms stipulated by the Law, a deputy shall be free to irrevocably put his/her term of office at the disposal of the political party upon whose proposal he/she has been elected a deputy."

10 It was one of the rare occasions in the analysis of the new Serbian Constitution of 2006 where most of the domestic authors agreed with the opinion of the Venice Commission experts. The Serbian scholars warned about such a danger in numerous papers published after the year 2000. (Stojanović, 2003; Pajvančić, 2003; Jovanović, 2005; Marković, 2006; Goati, 2007; Pejić, 2000/2001; Pejić, 2007; Nenadić, 2008.) 
would reaffirm the political reality), or should the state insist on the fundamental values underlying the democratic constitutionality and return the MP's mandate into the general framework of popular sovereignty? It would be unacceptable to allow the political parties to have the parliamentary mandates at their free and full disposal because there is a danger that political parties would assume all the power for themselves by taking over the role of the electoral body and appropriating the citizens' sovereignty. The constitutional principle of popular sovereignty imposes immanent restrictions on political representation; namely, even though the political parties have a predominant role in the electoral process and physically "occupy" the parliament, their role is limited by popular sovereignty in the rule of law system.

\section{Constitutional Measures Upholding the Fundamental Principles}

In order to clarify the roots of the problem, we shall return to the previously postulated dilemma: how to interpret the basic constitutional principles without compromising their original contents but respectfully taking into account the changes in the evolution of the value system? The concept of the separation of powers was originally created as a "static construction" in the specific historical circumstances when the concept of absolute monarchy was abandoned but the constitutional monarchy was still undeveloped. The "political dynamism" of the $20^{\text {th }}$ century was the reason for blending the functions of the legislative and the executive power, all of which called for a new interpretation of the "old" principle (Loewenstein, 1938: 567). While the power of political parties was on the rise, the power of the elected representative body in parliament was in decline. Today, political parties do not exercise their constitutional role only in the electoral process but also by exerting constant pressure on the operation and behavior of elected parliamentary representatives. Political representation has obtained a secondary function: internal representation within the party structure, which is reflected in the composition and operation of parliamentary groups as well as in the position of elected representatives. As opposed to the liberal perception of elected MPs as "spokespersons" of the people, the present-day conception is based on developing strong and permanent bondsbetween the political party and (its) parliamentary representatives.

In spite of being challenged and even whole-heartedly defied in constitutional theory, the party discipline of the elected MPs has become a reality (even though it does not enjoy any legal protection). The parliamentary practice has yielded a new "profile" of MPs who are in toto politically dependent on their party because they largely express their attitudes, opinions and positions in camera, within an enclosed, unitary and unanimous political group in parliament. Today, the 
parliamentary mechanism is set in motion by parliamentary groups, whose activities are crucial for the operation of the representative body because they determine the dynamics of decision-making processes. The parliamentary groups discuss the political agenda and formulate the basic political goals, which are further negotiated and decided in parliamentary sessions. Any prior legal decision broughtin a political center is prejudicial to the parliamentary decisionmaking processes because the parliamentis constitutionally obliged to decide on the matter. Hence, instead of being an individual activity of elected MPs, the parliamentary activity is increasingly turning into a collective activity. Members of parliament have to adjust their demeanor to the role of the specific political group in the parliamentary process, for which reason their individual potentials and their immanent right to take action often put on hold (Gicquel, 1997: 691).

The content of the mandate and its legal nature are necessarily associated with the idea of accountability in representative democracy. In that context, we need to address the following question: whether and to what extent are the MPs accountable to their constituents? Being part of the general framework of the principle of free parliamentary mandate, the relations between the voters and their elected representatives indicate that MPs are not directly accountable to the voters because their relationship is not officially institutionalized in the form of a recall. On the other hand, the principle of representation necessarily entails a contact between the voters and the elected MPs, which is not contradictory to the traditional standpoint on the free parliamentary mandate developed by E.BurkeandJ.S.Mill. Thus, the party discipline has become a reality and " $(t) h e$ praise of party control is mostly based on the legislative functions of parliament" (Beyme, 2000: 71). Since the promulgation of the free parliamentary mandate, legal responsibility of parliamentary representatives is almost extinct in many parliamentary systems. The free parliamentary mandate ensures the continuity of the MPs function and excludes the possibility of MPs recall. On the other hand, non-legal responsibility of parliamentary representatives may be expressed through the concept of "accountability" to the voters. The "accountability" test may be performed either periodically (in elections) or constantly (in the process of adopting legislative acts when the government policy receives a majority support in parliament). Therefore, the concept of accountability of constitutional authorities may be said to have its roots in the mechanism of parliamentary elections, when the voters choose the political majority which will constitute and support the elected government during its term of office.

In order to provide for the development of the system of representative democracy as a fundamental value of the constitutional order, it is necessary to regulate a set of "constitutional measures" which would ensure the accountability of the elected representatives. To that effect, it is essential to strengthen the 
position of the electorate as a constitutional body per se. This opinion is based on the assumption that the basic rules of representation (such as the rule on direct and free elections) should be implemented in a state where "the citizenship right establishes a link between popular sovereignty (as the cornerstone of democratic institutions) and political choice" (Masclet, 1989: 14).

The first measure, which is likely to be the most contested one, would be to introduce the concept of compulsory voting, i.e. the obligation to vote. Considering the motive for introducing such a radical measure in the field of electoral rights, we consider that the compulsory voting will contribute to strengthening the legitimacy and restore confidence in constitutional institutions. The exercise of the right to vote in elections is the most significant act in shaping and confirmingthe citizens' political will in the representative democracy; citizens' participation in elections is the most explicit way of providing for their participation in decisionmaking processes. The election process establishes and verifies the legitimacy of the governing power, and endorses the government's prospective action and administration. On the other hand, the freedom of choicepresumes and justifies the concept of civil allegiance, which may be reinforced by introducing the rule on compulsory voting.

The concept of compulsory voting has been challenged in terms of "limiting" the freedom of choice. Being fully aware of the justified criticism, we consider that introducing a rule on compulsory voting may contribute to increasing the citizens' active participation in elections and raise their awareness about the accountability of elected officials. If the voters were obliged to take their share of responsibility by voting in elections, their expectations from the elected representative might be higher. Accordingly, the idea of free parliamentary mandate would fulfill its value-driven mission, which is to ensure that the MPs take into account not only the standpoints of their political parties but also (if not more) the opinions of their constituents.

Another "measure" would be the change of the electoral system by introducing a mixed model combining the majority election system and the proportional representation system, and increasing the electoral census for coalition lists. Considering that the electoral system is the foundation of representative democracy which concurrently ensures the legitimacy of the governing power, the "choice" of electoral system is one of the important factors in creating a legal and political environment for exercising the constitutional principles in the rule of law. In the course of "selecting" the election system, it is important to take into account the historical, social and particularly political circumstance underlying the development of the system. Conversely, constitutional authorities must consider the effects of particular election models because they significantly affect 
the organization and operation of the constitutionally established system of government. There is general consensus that the majority election system leads to establishing a unified, stable and coherent government, whereas the proportional election system results in creating heterogeneous coalition governments which (on the other hand) meet the subtle requirements that ensure both political and social representation to different minority groups (Norris, 1997: 310). Taking into consideration the advantages of these election systems, we consider that a combination of these two models would provide for a more substantial protection of citizens' sovereignty and their right to vote.

The prohibition of recomposing the parliamentary assembly during one legislaturemay be regarded as a special "measure" although it might fall within the scope of parliamentary rules aimed at regulating the internal structure and organization of parliament. The status of the so-called independent representatives should be regulated in more detail as it happens that these MPs hold their mandatesuntil the legislature's term of office expires but they may not join any other parliamentary group because the parliamentary groups had been constituted much earlier, in the first session of the new parliamentary assembly.It follows that the composition of a parliamentary group may not be subsequently expanded. Concurrently, the status of individual (independent) parliamentarians elected in majority elections should be reinforced and they should be empowered by assuring their equal participation in all stages of the parliamentary process.

Finally, it may be necessary to establish a new legal framework which would facilitate a direct contact between the voters and their elected representatives through electoral bodies in the local territorial units whose primary task would be to enable direct communication between the voters and (their) MPs. It would reinforce the idea of balanced territorial representation in the national parliament and make the elected MPs directly accountable to their voters. This measure would be particularly prominent in the combined electoral system, where the MPs elected under the majority election system are expected to truly represent the specific interests of the constituents in their electoral unit. Thus, in addition to periodic confidence checks (through elections), elected representatives would be able to keep in touch with the voters; it would ultimately enhance their activity in raising parliamentary questions and launching legislative initiatives.

All the above instruments may be described as a set of constitutional measures aimed at "defending" the system of fundamental values in the constitutional state. These measures may reinforce the (almost extinct) idea embodied in the liberal constitutionality concerning the accountability of all holders of constitu- 
tional power, including the elected members of parliament. The entire concept stems from the idea that, under the principle parsprototo, the constitutional instruments have to activate the potentials of the electoral body and the elected representatives alike; ultimately, there is less leeway for manipulative actions of different intermediaries in the electoral process.

\section{Conclusion}

The contemporary trends in constitutional design show that the constitution as the supreme legal act is no longer an original country-specific legal document because the constitutional principles are taken over from the constitutions of other states. However, the specific model of replicating the fundamental constitutional principles from other constitutions generates another problem in the process of creating the system of fundamental values. Nowadays, all constitutional documents include constitutional guarantees on the rule of law but the constitutional document does not presume that the citizens will have equally well-developed value judgments on the constitutionally guaranteed rights/ freedoms and their significance. It is evident, for example, in the principle of representation and representative mandate, which has raised some doubt among citizens in the new constitutional order of the Republic of Serbia, particularly regarding the following issue: who is the actual holder of power,i.e. who is the holder of sovereignty in the constitutional state?

The adoption of the first or a new constitution presumes constituent power which is not subject to any state-imposed restrictions; yet, we may not disregard the impact of other non-legal factors which considerably affect the understanding, interpretation and implementation of constitutional principles. Although there is general consensus among the legal scholars, professionals and the constitutional judicature in terms of "defending" the model of free parliamentary mandate, it may not prevent the politicians from trading off their mandates and depriving citizens of their basic human liberties: the freedom of thought, opinion and expression. We consider that this issue has to be approachedin a comprehensive manner; the concept of MPs' parliamentary mandate must be observed in light of the parliamentary representation system where all the holders of constitutional powers will take responsibility for their actions, including the electoral body in the capacity of the "original" constitutional authority.

Given the fact that the election process establishes and confirms the legitimacy of the governing power, elections justify civil allegiance, which may be expressed through compulsory voting. The institutionalization of the compulsory voting may be beneficial because citizens would be obliged to assume more responsibility for the choices they make in the election process, which may ultimately 
raise their awareness about the MPs role and their expectations from the elected representatives. Accordingly, the content of the free parliamentary mandate would justify its value-driven mission: to ensure that the elected MPs take into account not only the standpoints of their political parties but also (if not more) the opinions of their constituents.

\section{References}

Ackerman, B. (1997). The Rise of World Constitutionalism. Faculty Scholarship Series. Paper 129. 771-797. Retrieved from: http://digitalcommons.law.yale.edu/ fss_papers/129.

Beyme, K.v. (2000). Parliamentary Democracy: Democratization, Destabilization, Reconsolidation, 1789-1999. London: MacMillan Press.

Burdeau, G., Hamon,F., Troper,M.(1995). Manuel Droit Constitutionnel. Paris: LGDJ. Gicquel, J. (1997). Droit constitutionnel et institutions politiques. Paris: Montechrestien

Goati, V. (2007). Parlamentarizam i partijski sistem Srbije. U V.Pavlovići S.Orlović (ur.). Dileme i izazovi parlamentarizma. (str. 129-140). Beograd: Fakultet političkih nauka. Konrad Adenauer Stiftung.

European Commission for Democracy through Law (Venice Commission), Opinion on the constitution of Serbia, adopted by the Commission at its $70^{\text {th }}$ plenary session, 17-18 March 2007 (Opinion No 405/2006).

Fleiner, L.B. (2001). Relevance of Western Legal Expertise to Rule of Law in Countries in Transition. In: Legal Framing of the Democratic Control of Armed Forces and the Security Sector: Norms and Reality/ies. (Ed.B.Veljanovska). Belgrade. 32-41.

Go, J. (2003). A Globalizing Constitutionalism? Views from the Postcolony 19452000. International Sociology. 18 (71). 71-95.

Jovanović, M. (2005). Slobodni mandat - ustavnopravni fosil?. Srpska politička misao.14(1-2). 53-78.

Јовичић, М. (1977). О уставу. Београд: Институт за упоредно право.

Köchler, H. (1995). A Theoretical Examination of the Dichotomy between Democratic Constitutions and Political Reality. Paper presented at the Colloquium New Paths of Democracy. University Center of Luxembourg. Retrieved from: www.politicaltheory.info/2004/february.html.

Komberg, A. (1966). Perception and Constituency Influence on Legislative Behavior. The Western Political Quarterly. 19(2). 285-292. 
Krouse, R.W. (1982). Two Concepts of Democratic Representation: James and John S.Mill.The Journal of Politics. 44(2). 509-537.

Loewenstein, K. (1938). The Balance between Legislative and Executive Power: A Study in Comparative Constitutional Law. The University of Chicago Law Review. 5(4).

Lutz, D.S. (2006). Principles of Constitutional Design. Cambridge University Press. Марковић, Р. (2006). Устав Републике Србије из 2006 - критички поглед. Анали Правног факултета у Београду. LIV(2). 5-46.

Masclet, J.C. (1989). Droit électoral. Paris: Presses Universitaires de France.

Maunz, T., Zippelius, P. (1994). Deutsches Staatsrecht. München: C.H.Beck`sche Verlagsbuchhandlung.

Ненадић, Б. (2008). 0 парламентарном мандату: пример Републике Србије. Анали Правног факултета у Београду. LVI(1). 5-25.

Norris, P. (1997). Choosing Electoral Systems: Proportional, Majoritarian and Mixed Systems. International Political Science Review. 18(3). 297-312.

Пајванчић, М. (2003). Устав је погажен. Гласник Адвокатске коморе Војводине. Бр. 3. 98-106.

Pasquino, P. (1998). Constitutional Adjucation and Democracy. Comparative Perspectives: USA, France, Italy. Ratio Juris 11. 1998(1). 38-50.

Пејић, И. (2000/2001). Правне последице фракцијске дисциплине у парламентарном процесу. Зборник радова Правног факултета у Нишу. Бр. XL-XLI. 106-119.

Пејић, И. (2007). Парламентарни мандат у Уставу Србије. Избор из судске праксе, Бр. 3. 5-11.

Rahat, G. (2007). Candidate Selection: The Choice before Choice. Journal of Democracy. 18(1). 157-170.

Стојановић, Д. (2003). 0 уставности одредаба чл. 88 ст. 1 тач. 1 и 9 Закона о избору народних посланика. Гласник Адвокатске коморе Војводине. Бр. 3, 91-97.

Turpin, C. (2002). British Government and the Constitution. Butterworths, Lexis Nexis.

Hesse, K. (1982). Grundzugedes Vefassungsrechts der Bundesrepublik Deutschland, Heidelberg: Müller. 
Др Ирена Пејић,

Редовни професор Правног факултета,

Универзитет у Нишу

\section{Основне вредности у новим демократијама: Принцип репрезентације у Уставу Србије}

\section{Резиме}

У раду је учињен покушај да се расветли однос између фундаменталних вредности у уставној држави и уставних принципа о представништву и представничком мандату. У првом делу начелно се разматрају услови у којима уставотворна власт формира вредносни систем, уважавајући (ван)правне чиниоце који доприносе уобличавању и интерпретативној еволуцији уставних принципа. Доношењем првог устава ствара се правни образац у коме се развијају темељне вредности новог поретка. па се стога ова два поља, уставни и вредносни, не могу посматрати одвојено јер су комплементарна и међусобно условљена. Основни принципи, којима се гарантује владавина права, садржани су у готово свим уставним документима на крају двадесетог века, али то не значи да грађани имају једнако изграђен вредносни суд о њима и о њиховом значају. То се може видети на примеру начела о представничком мандату који је, више него други уставни принципи у тзв. новим демократијама, произвео сумњу код грађана о томе ко је стварни носилац суверености у уставној држави.

Успостављању хармоније између прокламованих принципа и темељних вредности могу допринети одређене уставне мере. Концепт парламентарног мандата треба посматрати кроз оптику представничког система у коме одговорност носе сви носиоци власти, укључујући и бирачко тело са својством „изворног“ уставног органа. С обзиром да се путем избора установљава и оправдава легитимна власт, избори оправдавају грађанску послушност која може бити оснажена правилом о обавезности гласања. Уколико своје право гласа врше као јавну функцију, грађани би били суочени са одговорношћу за вршење избора, а то би могло имати за последицу да њихова очекивања према изабраним представницима буду већа. На овај начин, могла би се оснажити готово угасла идеја либералне уставности о одговорности свих носилаца власти, укључујући и национални парламент кроз његову примарну обавезу „полагања рачуна“ бирачима. Овде разматрани концепт полази од тога да се уставним инструментима морају у потпуности активирати потенцијали како изабраних представника, тако и бирачког тела, што би оставило мање простора за манипулативно деловање посредника у изборном процесу и у изабраном представништву.

Кључне речи: принцип репрезентације, парламентарни мандат, уставна демократија, Устав Србије. 